\title{
AS RELAÇÕEs ENTRE POESIA DIDÁtICA E FILOSOFIA. HESÍODO, PARMÊNIDES E EMPÉDOCLES ${ }^{1}$
}

Maria Cecilia Colombani²

\begin{abstract}
Resumo
O projeto do presente trabalho consiste em recuperar certa função didática que verifica-se nos vínculos que podemos estabelecer entre poesia e filosofia. Em primeiro lugar, transitaremos por alguns tópicos que se encontram na função didática da poesia de Hesíodo no que diz respeito à sua relação com seu irmão Perses. Em segundo lugar, iremos analisar o papel da Deusa no Proêmio do Poema de Parmênides. Finalmente, nos localizaremos no Poema de Empédocles para ver a dimensão didática que ali se desempenha no marco dos papéis que desempenham Empédocles e um tal Pausânias.
\end{abstract}

\section{Palavras-chave}

Poesia; Filosofia; ensino; Hesíodo; Parmênides; Empédocles.

\section{Resumen}

El proyecto del presente trabajo consiste en recuperar cierta función didáctica que parece darse en los vínculos que podemos establecer entre poesía y filosofía. En primer lugar transitaremos por algunos tópicos que se encuentran en la función didáctica de la poesía de Hesíodo en lo que concierne a su relación con su hermano Perses. En segundo lugar, revisaremos la función de la Diosa en el Proemio del Poema de Parménides. Finalmente, nos ubicaremos en el Poema de Empédocles para ver la dimensión didáctica que allí se despliega en el marco de los papeles que desempeñan Empédocles y un tal Pausanias.

\section{Palabras clave}

Poesía; Filosofía; didáctica; Hesíodo; Parménides; Empédocles.

\footnotetext{
${ }^{1}$ Traduzido do espanhol por: Amanda Martins Hutflesz e Viviane Roza de Lima.

2Professora Doutora, Universidad de Morón, Morón, Argentina. email: ceciliacolombani@hotmail.com
} 


\section{Introdução}

O projeto do presente trabalho consiste em recuperar certa função didática que pode ser estabelecida nos vínculos entre poesia e filosofia; sendo esta dimensão, sem dúvida, uma das mais significativas no contexto da relação que nos propomos a investigar ${ }^{3}$.

Ao relevar esta função trataremos, em primeiro lugar, de passar por alguns tópicos que podem ser encontrados em Hesíodo, especialmente em Trabalho e Dias, a partir da função didática com que o poeta desempenha em relação ao seu irmão Perses. Em segundo lugar, tentaremos explorar o papel da Deusa no Proêmio do Poema de Parmênides, antes da chegada do iniciado, após a viagem que empreendera conduzido pelas Helíades, filhas luminosas do Sol. Finalmente, nos colocaremos no Poema de Empédocles para revelar a dimensão didática que se desenrola no âmbito do papel que desempenham Pausânias e um tal de Empédocles, médico prestigiado de Agrigento, como aquele que é iniciado pelo autor.

\section{Hesíodo de Ascra}

Se a Teogonia permite relevar certas marcas didáticas, a partir da familiaridade de Hesíodo com as Musas, primeiras mestras de alétheia; queremos concentrar-nos em Trabalhos e Dias para relevar o tópico e colocá-lo em uma relação mais horizontal entre o poeta e seu irmão (Detienne: 1986).

Em primeiro lugar, a invocação às Musas de Pieria coloca a missão hesiódica sob a mesma proteção que tivera em Teogonia e, portanto, sob o mesmo ensinamento que as deusas lhe conferem para cumprir uma missão de claro corte didático (Colombani, 2005). A ritualização discursiva, presidida pela autoridade das Musas, confere à palavra de Hesíodo o mesmo registro de poder que elas próprias ostentam, ao mesmo tempo em que fecham o discurso dentro do âmbito de uma

\footnotetext{
${ }^{3}$ Cada vez que fizermos referência à poesia o faremos a partir uma dupla vertente, seu vínculo com a sabedoria e sua relação com a transmissão de um saber prestigioso que exige uma verdadeira ritualização do sujeito falante, as circunstâncias em que a mensagem é transmitida e a própria palavra que precisava ser ensinada. Tripla excepcionalidade do mito, como aquele logos que constitui uma primeira tentativa de dar conta do real, intimamente relacionado com o presente trabalho.
} 
determinada sociedade secreta, defendida e protegida no contexto da poesia sábia, onde a dimensão didática domina a cena ${ }^{4}$.

Pensemos em Teogonia. Quando as Moûsai se aproximam do poeta, abrindo a distância que os separa de seus respectivos planos de existência, introduzem a possibilidade da mentira como uma nota constitutiva da sua vontade abrangente:

¡Pastores del campo, triste oprobio, vientres tan sólo! Sabemos decir muchas mentiras con apariencia de verdades; y sabemos, cuando queremos, proclamar la verdad. Así dijeron las hijas bienhabladas del poderoso Zeus. $Y$ me dieron un cetro después de cortar una admirable rama de florido laurel. Infundiéronme voz divina para celebrar el futuro y el pasado y me encargaron alabar con himnos la estirpe de los felices Sempiternos y cantarle siempre a ellas mismas al principio y al final (Hes. Theog. 27-34)5.

Trata-se da dimensão da palavra litúrgica, de registro mítico e sacralizado que sai da boca das deliciosas mestras da verdade. Sempre uma palavra de louvor, um lógos theókrantos, que celebra os Sempiternos Imortais. Neste contexto, são elas que, a partir de um tópos ambíguo, sabem dizer muitas mentiras com aparência de verdade (pseudéa), mas sabem dizer a verdade quando lhes agrada.

A verdade é sempre a herança dos deuses e é jogada como parte de uma lógica do dom, porque são eles que escolhem quem pode "vê-la" e cantála. O dom da clarividência de um poeta inspirado e o canto que flui de sua boca constituem a equação de uma aproximação à verdade. Coloca o poeta no espaço de excepcionalidade ontológica que possui na província de mágico religioso.

No entanto, esta palavra nem sempre constitui uma abordagem à verdade, porque quando se apresenta em um cenário impregnado pela ambiguidade como nota constitutiva, pode ofuscá-la; se as Moûsai podem dizer tanto a verdade como as coisas aparentes, então possuem a capacidade de pronunciar coisas verdadeiras, mas também de ocultá-las, tampá-las, cobrí-las e não permitir que a alétheia aconteça, brilhe, no quadro de uma metáfora de luz onde fica tensa a clareza da sua revelação e a escuridão de seu encobrimento.

\footnotetext{
${ }^{4}$ Em A ordem do discurso, Michel Foucault analisa a relação entre o discurso e o poder e releva o que ele chama de rareamento dos sujeitos, como um mecanismo de controle da intervenção e para mostrar como o campo do mesmo não tem a mesma permeabilidade por todos os seus poros; pelo contrário, existem áreas de intervenção altamente protegidas e que continuam nas mãos de poucos, que as ostentam a partir de certas qualificações próprias. Entre esses mecanismos de controle se encontram as chamadas "sociedades secretas".

${ }^{3}$ Todas as citações de Hesíodo seguem a tradução de Pérez Jiménez, 2000.
} 
A sabedoria, essa espécie de filosofia popular (Gernet, 1981), é resolvida dentro dessa lógica, desta tensão entre o verdadeiro e o coberto que, no campo poético, dominado por um poeta visionário de registro hesiódico, toma a forma de uma palavra sacralizada, ordenação da realidade como um todo. No plano oracular, presidido pela terribilidade de Apollo (Colli: 1994), adquire a forma de uma palavra mântica, associada à manía como estado extraordinário, que deve ser revelada e descoberta pelo prophetés e, no âmbito da soberania, toma a forma de uma sentença divina, de caráter definitivo, porque a justiça é sempre patrimônio dos deuses.

Em Trabalhos e Dias o registo do magistério é dado pela própria história que põe em jogo o poema; características de caráter autobiográfico que complicam as relações entre Hesíodo e Perses posicionam ao primeiro no lugar da prudência, sophrosýne, o esforço e o trabalho, como marcas da areté, frente a seu irmão Perses, no lado oposto da tensão, resulta ser contra-modelo antropológico-cultural.

A capacidade didática de Hesíodo está legitimada por sua condição moral, que contrasta em um jogo de espelhos invertidos com a condição moral de seu irmão. A partir desta diferença de atitude em relação à vida que é que Hesíodo afirma: "yo trataré de poner a Perses en aviso de la verdad" (Hes. Op. 10-11)

Retorna, assim, uma característica do que era o suporte didático de Teogonia: falar ou agir em nome da verdade, já que a ele as deliciosas filhas do Pai lhe disseram as coisas verdadeiras, tá alethéia, além de que podem pronunciar coisas enganosas, tá pseudéa, com aparência de verdades7. A missão didática de Hesíodo está garantida por estar na verdade das coisas, aletheian, e agir em conformidade, advertindo seu irmão no gesto didático, o que não poderia ser de outra forma: " $\mathrm{OOh}$ Perses, grábate tú esto en el corazón!" (Hes. Op. 28).

O ensino da poética está apoiado pela familiaridade com as Musas, a quem tem invocado para iniciar o canto, e o permitem narrar, mythéo, aqueles mythoi, em tantas histórias significativas, sagradas, verdadeiras e

\footnotetext{
${ }^{6}$ Hes., Op. et di., 10-11.

${ }^{7}$ Com base no trabalho de Gigon, tanto em As origens da Filosofia Grega bem como em Problemas fundamentais da filosofia grega, a leitura que tem feito a crítica, da qual nos baseamos e seguimos como marco interpretativo, tem localizado a Hesíodo nessa zona escura, de fronteiras imprecisas entre poesia e filosofia, própria da Grécia arcaica; além disso, ele trabalhou os núcleos filosóficos presentes na Teogonia como relato emblemático da totalidade. O problema do ser, do todo, da origen, da verdade e da transmissão da verdade tem sido os fios que Gigon encontrou para alinhavar o tapete do Hesíodo-filosofo.
} 
arquetípicas $^{8}$ A partir desse poder-saber, Hesíodo aborda Perses para oferecer-lhe o relato fundador: "Ahora si quieres te contaré brevemente otro relato, aunque sabiendo bien - y tú grábatelo en el corazón - cómo los dioses y los hombres mortales tuvieron un mismo origen" (Hes. Op. 106-108) $)^{9}$.

Da mesma forma, a autoridade que lhe conferem tanto pela presença da verdade como as condições morais que o assistem, lhe permitem dirigirse aos os reis em uma mesma atitude didática. $\mathrm{O}$ magistério poético recebido pelas Musas permite-lhe denunciar e enfrentar o poder daqueles em posição de autoridade política na aldeia; uma autoridade desvalorizada em termos morais a partir das práticas de termos discursivos dos dorophágoi. $\mathrm{O}$ confronto que o poeta realiza está legitimado, mais uma vez por sua autoridade moral, que o habilita a ser um mestre da alétheia. A dimensão didática de matriz corretiva é então materializada em advertência:

iOh reyes! Tened en cuenta también vosotros esta justicia; pues de cerca metidos entre los hombres, los Inmortales vigilan a cuantos con torcidos dictámenes se devoran entre sí, sin cuidarse de la venganza divina (Hes. Op. 249-252).

Além deste desafio de impacto político, o relato emblemático que desenvolve o ensino hesiódico destina-se ao seu irmão. Sua dimensão didática está diretamente associada ao saber que possui sobre questões mais práticas: "Yo que sé lo que te conviene, gran necio Perses, te lo diré: de la maldad puedes coger fácilmente cuanto quieras; llano es su camino y vive muy cerca" (Hes. Op. (287-289).

Apenas escolhemos este aviso como um exemplo de uma série de dicas, recomendações e exortações com que Hesíodo se dirigiu a seu irmão em atitude corretiva e de mudança de vida. Para lograr alguma mudança sobre a conduta de Perses é necessário iniciá-lo a partir de um espaço didático, mesmo frente à proximidade de idades entre ambos os irmãos.

No entanto, deve esclarecer-se que a dimensão didática se estende muito além das fronteiras de seu próprio irmão. A organização do dispositivo de trabalho, como ele reconhece o trabalho, suas recomendações, o corpus de conhecimento implantado, torna o poema em um logos aberto a todos os membros da comunidade de agricultores. O seu magistério é o topos a

\footnotetext{
8 Mircea Eliade, na Estrutura dos mitos, enuncia estes quatro adjetivos que dão o mythos, depois de ter separado da visão do século XIX, onde a história mítica está associada com a ideia de um pensamento incompleto, selvagem e imperfeito, típicos de uma fase adolescente da humanidade. Eliade retoma o mito da sua lógica complexa, colocando-o a par com outros sistemas de pensamento para perceber a complexidade da realidade.

${ }^{9}$ Seguindo a Pérez Jiménez, se aceita a correção de A. García Calvo.
} 
partir do qual se constrói a rotina de trabalho, que organiza a vida individual e a identidade do grupo de agricultores. Até aqui uma primeira relação entre poesia e filosofia, lida a partir de uma linha de vida educacional, aclarando que nossa perspectiva localiza a Hesíodo como um primeiro filósofo.

\section{Parmênides de Eléia}

Em segundo lugar, realizaremos uma análise do Proêmio do poema de Parmênides a partir da mesma atitude didática. Parmênides floresceu em 500 a.C. Sua presença constitui um marco importante na chamada filosofia pré-socrática, no âmbito da primeira especulação naturalista; apesar de sua importância e peculiaridade se arraiguem precisamente em afastar-se dessa tradição, o que faz do estudo da natureza o objeto de investigação, para começar outro atalho dentro do pensamento, marcado por viés metafísico, de preocupação com o Ser.

No entanto, este aspecto da filosofia de Parmênides não é o que queremos abordar, mas uma certa relação com a tradição poética que é exibida no Proêmio e, a partir daí, resgatar a presença do feminino no contexto do ensino; que parece vinculá-lo com Hesíodo, onde a iniciação poética inclui a presença das Musas como nota dominante e dispositivo didático como um evento filosófico.

O Proêmio possui um tom poético e é um tipo de introdução que abrange trinta e dois versos que constituem o fragmento, ao mesmo tempo em que possui características bem diferentes do resto do Poema (Cordero: 2005); insere-se em um fundo mítico religioso, que destaca do tom argumentativo posterior. Múltiplas imagens recortam-se das impressões da tradição poética arcaica de onde podemos ter linhas de interseção.

O fragmento 1 relata a experiência de uma viagem da qual o próprio Parmênides é protagonista e narrador, similar à experiência hesiódica, descrevendo uma situação de iniciação semelhante, em que a presença feminina é determinante. Tanto a um como ao outro, as deusas os levam, os transladam de um tópos a outro como forma de iniciar uma viagem teleológica cujo objetivo final é a verdade.

São dois registros femininos que podemos resgatar. Do versículo 1 a 23, a descrição da viagem oferece a imagem de uma carruagem puxada por 
dois cavalos e guiada por algumas jovens donzelas, as Helíades, filhas do sol $^{10}$.

A carruagem deve atravessar as portas do Dia e da Noite para terminar chegando à morada de uma deusa, deixando nervosa a díade escuridãoclareza; da noite vêm as jovens aurigas e para o dia encaminham-se ${ }^{11}$. A partir do verso $24 \mathrm{faz}$ seu aparecimento o segundo elemento feminino: a Deusa, de marcada matriz didática, que completará a revelação. Interpretamos que a guia das jovens Helíades constitui um primeiro momento da iniciação-revelação, já que conhecem o caminho por onde conduzir a jovem.

A Deusa, cujo nome não sabemos, recebe Parmênides e segue em sua boca todo o poema, em uma exibição de saber que ela parece personificar. Depois do cumprimento inicial, a Deusa dá as boas-vindas a Parmênides, ao mesmo tempo em que o felicita por ter atingido esse lugar desde o território dos mortais. Por último, entre os versos 28 e 31, a Deusa dá mostras de seu saber, revelando ao recém chegado o que o resto dos mortais não conhecem.

Yo te alejo...de aquello (el camino de investigación) sobre lo que yerran los mortales de dos cabezas, que nada saben, pues la insensatez dirige en sus pechos el vacilante pensamiento. $Y$ se agitan de aquí y allá, mudos y ciegos, tontos; muchedumbre de insensatos, para quienes el ser y el no ser les parecen lo mismo y no lo mismo, y el camino de todas las cosas se halla en direcciones opuestas (Parm., De nat. fr. 6; versos 4-9)12.

A Deusa dirige-se ao jovem com gesto didático advertindo-lhe o coração sobre a verdade do Ser. A advertência refere-se aos homens de duas cabeças que confiam no depoimento dos sentidos, onde a multiplicidade e a mutabilidade de se tornar exibem a interseção de ser e não-ser.

Além desta mensagem, que não é a nossa intenção analisar, o que sim surpreende é a dissimetria estatutária entre a Deusa, que parece conhecer

\footnotetext{
${ }^{8}$ A carruagem é puxada por cavalos, mas sem a presença de um condutor; são precisamente as jovens donzelas as que a puxam, mostrando às éguas o caminho de uma viagem onde são elas as que parecem conhecer o caminho, posicionando-se em um lugar de saber. As donzelas têm posto o jovem no caminho da divindade porque conhecem o mesmo. Condução e saber parecem ser as notas das filhas do Sol.

${ }^{9}$ Surge uma notação lumínica que nos permite territorializar as donzelas no marco de uma zona lumínica. As Helíades são filhas da Luz e abandonam precisamente as mansões da Noite, deixando nervosa a díada Noite-Dia, Luminosidade-Tenebrosidade. Resultam, como as Musas, em divinidades de sinal luminoso, de registro diurno, aparentadas com elementos luminosos como o sol ou o próprio Zeus em sua condição de Pai luminoso.

12 Todas as traduções dos fragmentos analisados pertencem a R. Mondolfo, 1980; neste caso, $\mathrm{p}$. 78.
} 
a verdade e pode ensiná-la, e os homens de duas cabeças, destinados a aprender. Neste ponto, a relação com Hesíodo é significativa porque um mesmo recurso põe a ambos em um plano de semelhança. Ambos colocam a verdade na boca da divindade. São as deusas, as Musas Heliconíades, no caso de Hesíodo e esta deusa inominada, no caso de Parmênides, as que ostentam o poder de dizer a verdade, de transmitir com gesto didático, e corresponde aos homens, "pastores del campo, triste oprobio, vientres tan sólo" ou bem os "mortales de dos cabezas" escutá-la.

Pero tú, aleja tu pensamiento de esta vía de investigación y que no te empujen en ella el hábito empírico de dejar dominar el ojo desprovisto de un fin, y el oído rumoreante y la lengua. Pero juzga con la razón, la prueba tan discutida, afirmada por mí (Parm, De nat., 1, 33-37 = 7, 2-5 D.-K.)13.

Advertimos o tom didático-exortativo da Deusa, que ostenta a autoridade que seu poder lhe confere para recomendar ao jovem afastar o seu pensamento da via impraticável. Reafirma o valor da razão como único critério válido de investigação e volta a insistir em tom instrutivo:

Vamos, yo te diré - y escuchando el discurso consérvalo en ti- las dos únicas vías de investigación que se puedan concebir. La una, que (el ser) es y no puede no ser: ésta es la vía de la Persuasión, porque se halla acompañada de la verdad; la otra, que no es y que es necesario que no sea: y éste, te digo, es un sendero en el que nadie aprenderá nada (Parm., De nat. 1, 33-37 = 2, 2-5 D.-K.).

A Deusa segue exercendo seu magistério, ao mesmo tempo em que exibe a verdade da única via possível. De sua boca sai a verdade como também saíam as coisas verdadeiras da doce voz das Musas em seu primeiro desenvolvimento didático.

A Deusa marca a diferença estatutária entre ela e o recém-chegado; adverte-lhe que lhe oferecerá um discurso em atitude de entrega de seu saber, mas que ele o deve conservar, em atitude receptiva, tal como se desempenha a relação entre mestre e discípulo. Mostrou-lhe as duas vias, a do ser e a do não ser como uma antítese irreconciliável e com isso o inicia na via do conhecimento.

É esse conhecimento o que a eleva acima do jovem que vai a ela com gesto inicial. É a equação saber-poder a que se exibe na cena didática e a Deusa insiste em seu registro de autoridade:

${ }^{13} \mathrm{O}$ texto de referência dos pré-socráticos segue sendo a edição de Diels-Kranz, portanto indicamos a correspondência nos fragmentos de D.-K. 
Pues tú no podrás conocer el no-ser -lo cual no es posible ni podrías expresarlo (4, 78). Es menester decir y pensar que el ser es, pues es posible que él sea, pero la nada no es posible: esto es lo que te ruego que consideres. Pues yo te alejo de esta primera vía de investigación (Parm., De nat. 4, 7-8+6, 1-3).

A Deusa opina o que pode ser conhecido e o que não, o que pode ser dito e o que não e, em tom exortativo e amigável, pede a seu interlocutor que considere essa verdade. Os fragmentos e a ênfase que colocamos sobre a atitude da Deusa aproximam Parmênides da tradição poética inscrita no magistério que estivemos rastreando. Poema e divindade compartilham num mesmo registro didático, em que as divindades cumprem uma nítida função de ensino, extensiva à ordem do poema que elas mesmas instituem desde seu saber.

São as Musas, as divinas filhas de Zeus e Mnemosýne as que uma vez ensinaram a Hesíodo seu belo canto, incapaz de atingir essas verdades sem seu auxílio; elas, as únicas mestras capazes de dizer a verdade. De um modo análogo, a Deusa dá as boas-vindas a quem nada sabe, com gesto amável, acolhedor, e se encarrega didaticamente da revelação como ato fundador do conhecimento do Ser, ao mesmo tempo em que fica, em ambos casos, delineada a binaridade de planos (Gernet, 1981: 15 ss), o humano e o divino, no marco da aliança saber-poder. A tríade conduçãorevelação-magistério é o próprio símbolo do gesto didático e da luminosidade que envolve a ambos Proêmios como lógoi iniciais.

Quando as jovens abandonam a Noite para ingressar à Luz, tiram o véu que as cobria. Nova marca da luminosidade que a iniciação põe em jogo e que privilegia o par de tensões que ambos os poemas parecem delinear em suas exposições cartográficas: o velado e o desvelado, o coberto pelo véu que as donzelas trazem das Mansões da Noite, e o desoculto que implica a ação de se retirar o véu. A remoção do véu parece marcar a mudança de topoi e a acolhida da Deusa será o momento de desocultação. Estamos sobrevoando o campo lexical do termo alétheia. O véu acompanha a estadia das donzelas na área escura, enquanto a saída envolve a ação de desocultação; da mesma forma, o dom das Musas Heliconíades é a passagem do poeta vidente para outro tópos como condição antropológica.

\section{Empédocles de Agrigento}

Em terceiro lugar queremos transitar por alguns aspectos do pensamento de Empédocles guiados pelo mesmo projeto pelo qual viemos transitando. Não somos movidos a analisar criticamente o discurso do filósofo, mas colocar-nos em seu poema, para amarrar, mais uma vez, a relação entre poesia e filosofia, e detectar, na medida do possível, os 
temas que apareceram nos dois pensadores anteriores. Vindo de uma rica cidade de Sicília, Acragante, é possível situar seu nascimento em 494 e sua morte em 434. Como diz A. Bernabé Pajares:

Con Empédocles regresamos a un mundo filosófico y literario más próximo al de Parménides, con una implicación íntima entre filosofía y religión, característica del sur de Italia, y con el verso épico y los recursos tradicionales como instrumento de expresión (2008, 181).

Dos fragmentos conservados, já que o original perdeu-se, pode ser observado seu conhecimento e admiração por Parmênides, bem como o conhecimento dos físicos jónicos. Escreveu dois poemas, cuja unidade é tema de discussão, um se referindo a uma sorte de ciclo cósmico e outro dedicado à transmigração das almas, a partir das sucessivas purificações, pelo qual recebe precisamente este nome. Como diz N. Cordero:

nada impide que ambos textos formen parte de un poema único, pues Empédocles, como casi todos los primeros filósofos, encaró la realidad como un todo, y la vida humana formaba parte de ese todo (2008: 97).

Basicamente, postula a existência de quatro componentes originários que existem desde sempre já que não há noção de criação, sendo o equilíbrio cósmico o jogo de tensões que mantêm essas quatro raízes, com base na existência de dois princípios opostos: o Amor e a Discórdia, concebidos a partir de uma analogia com a vida humana. De outra perspectiva, também esses elementos aparecem em Hesíodo, como Eros e Eris, para dar conta, em primeiro lugar, de um amor primitivo como força de atração que une e constitui um dos quatro primeiríssimos na cosmogonia hesíodica e, em segundo lugar, da discórdia como aquilo que separa e rompe o equilíbrio.

Como afirma Cordero:

Empédocles dirá que las cuatro cualidades son el origen de todo y por esa razón utilizará la palabra "raíces" para nombrarlas (una vez más, un término relacionado con la visión dinámica de la physis por parte de los griegos. Recuérdese que physis significa lo que está creciendo (2008: 97).

Quatro elementos são simbolicamente identificados com imagens míticas; nem água, nem fogo, nem terra, nem ar, mas Zeus, o brilhante, Hera, quem dá a vida, Aidoneu e Nestis:

Pareciera que Zeus representa al fuego (pues es brillante), Hera la tierra (que es tradicionalmente la tierra madre), Nestis, divinidad siciliana, parece representar el 
agua; sólo queda Aidoneo como imagen del aire, ya que su nombre significa algo así como "el invisible", y al aire no se lo ve (2008: 97).

mbém as duas forças opostas são representadas com imagens míticas como ponto que deve ser considerado na aliança entre poesia e filosofia. Assim, a força que une é Afrodite, Amizade, philótes; enquanto a que separa é Discórdia, néikos, Combate, Luta.

Vamos agora analisar a dimensão educativa que o poema exibe para estabelecer os pontos de contato. Concordamos com Bernabé Pajares quando diz:

Literariamente, Empédocles es un consumado poeta que domina las fórmulas y los recursos homéricos, a la vez que muestra una serie de aspectos nuevos, como el gusto por la palabra rica, el término raro y, sobre todo, por la ambigüedad buscada como efecto -lo que, dicho sea de paso, constituye un tormento para el traductor-. Su afición por la metáfora -brillante, rotunda- suscita la crítica de Aristóteles, que cree que este tipo de lenguaje poético se aviene mal con la, para él, necesaria claridad de la expresión filosófica, lo cual, si bien es cierto para la época del estagirita, no lo es tanto para la de Empédocles, una época en que las fronteras entre lo racional y lo poético, entre lo místico y lo filosófico, no se habían trazado aún con nitidez (2008: 183).

Neste quadro de limites pouco claros, passaremos a analisar alguns fragmentos significativos para nosso trabalho. Em primeiro lugar, rastrearemos a função das Musas que, como em Hesíodo, fazem seu aparecimento no Poema.

Alejad, pues, dioses, de mi lengua el extravío de esa gente

y encauzad por mi boca piadosa un límpido hontanar.

$Y$ a ti, virgen de la memoria fértil, Musa de albos brazos,

te suplico; lo que es lícito que oigan los seres de un día,

envíamelo, conduciendo desde las moradas de

la Piedad el carro dócil a la rienda (Emped., De rer. nat. $2=3$ D. $-K$.).

A invocação às Musas dá-se de maneira análoga ao que aparece em Hesíodo, onde o poeta se refere às deusas no marco de sua precariedade ontológica. Aqueles "pastores do campo, triste opróbio", sabem da impossibilidade de conhecer o que foi, o que é e o que será a partir de sua condição de simples mortais. São as Musas as únicas que podem assisti-lo e, por isso, constituem a condição de possibilidade do conhecimento. No caso de Empédocles, quem fala pede aos deuses que o encaminhem no caminho correto para evitar o desvio daqueles mortais que, como ele, podem equivocar a senda. Em seguida, dirige-se à Musa, reconhecendo, como em Hesíodo, sua prodigiosa memória, um legado da sua gloriosa mãe, Mnemosýne. A Deusa tem os mesmos temperamentos que apareceram em Hesíodo, sua condição virginal, sua memória sacralizada, 
os braços brancos, sinais de sua juventude, como a pele macia das Musas Heliconíades.

Recordemos o início de Teogonia:

Comencemos nuestro canto por las Musas Heliconíadas, que habitan la montaña grande y divina del Helicón. Con sus pies delicados danzan en torno a una fuente de violáceos reflejos y al altar del muy poderoso Cronión. Después de lavar su piel suave en las aguas del Permeso, en la fuente del Caballo o en el divino Olmeo, forman bellos y deliciosos coros en la cumbre del Helicón y se cimbrean vivamente sobre sus pies (Hes. Theog. 1-9).

São elas as que podem lhe dizer o que um simples mortal pode ouvir, se convertendo, assim, no auxílio dos homens tolhidos pelo tempo e a morte. As similitudes são notórias e o caráter didático das Musas fica nitidamente expressado:

iSalud, hijas de Zeus! Otorgadme el hechizo de vuestro canto. Celebrad la estirpe sagrada de los sempiternos Inmortales, los que nacieron de Gea y del estrellado Urano, los que nacieron de la tenebrosa Nýx y los que crió el salobre Ponto. Decid también cómo nacieron al comienzo los dioses, la tierra, los ríos, el ilimitado Ponto de agitadas olas y, allí arriba, los relucientes astros y el anchuroso cielo. [...] Inspiradme esto, Musas, que desde el un principio habitáis las mansiones olímpicas, y decidme lo que de ello fue primero (Hes. Theog. 104-115).

Concedam-me. Inspirem-me. Digam-me. O sublinhado dos verbos enfatiza o pedido de ajuda para conhecer o que era no começo ${ }^{14}$. Sem esse auxílio nada pode ser conhecido, conferindo, assim, um verdadeiro matiz religioso ao conhecimento, o que torna difícil o limite preciso entre poesia e filosofia. O magistério feminino é claro e as Musas constituem as mestras de uma verdade de difícil acesso.

De outro ângulo, a imagem da carruagem se relaciona com a tradição parmenídea, no ponto em que a viagem inicial supõe a deslocação desde um tópos a outro na ordem do conhecimento. Embora não apareça a imagem da carruagem, está sim presente a metáfora da viagem em Hesíodo porque, de algum modo, a posse-inspiração, enquadrada no campo lexical do verbo katochéo, constitui uma espécie de viagem para o além. A dimensão didática do fragmento é incontestável e inscreve-se nitidamente na tradição que viemos explorando.

Así pues, si a instancias de alguno de los seres de un día, Musa inmortal, tuviste a bien que nuestros desvelos hollaran tu interés, asiste ahora, una vez más, Calíope, a

${ }^{14}$ O. Gigon, cf. n. 9 
este suplicante, en su intento de exponer un relato cabal sobre los dioses (Emped. De rer. nat. $3=131$ D. - K.).

O novo fragmento reforça a dualidade de planos; os "seres de um dia" e a divindade ocupam, como sempre, espaços diferenciados: uns solicitam assistência enquanto a Musa, "de braços brancos", outorga a vontade. $\mathrm{O}$ auxílio solicitado é o pedido expresso para narrar um relato sobre os deuses, novo ponto de contato com a tradição hesíodica, do qual dão conta os versos escolhidos.

A exortação didática torna a convidar ao interlocutor a respeitar a palavra da musa como uma fonte de verdade e autoridade: "En los miserables es costumbre no dar crédito a la autoridad. Tú en cambio, tal como te exhortan las garantías de la Musa, aprende, tras haber desmenuzado en tu fuero interno mi argumentación" (Emped. De rer. nat. 6 = 4 D.-K.).

O fragmento não só reforça a distância entre os mortais e imortais, mas também define dois campos antropológicos: os dos homens incapazes de dar crédito à legitimidade e a autoridade divina, e os que, sim, podem fazê-lo a partir do reconhecimento do poder da Musa.

Então, considere alguns aspectos doutrinários reais da relação entre quem ocupa a função de transmissão e quem vem para receber conhecimento, no âmbito de uma dupla pedagógica, onde um transmite uma mensagem e outro torna-se o receptor da mesma.

$Y$ es que angostas son las mañas que por los miembros se extienden y muchas las vilezas que acucian y embotan las meditaciones.

Tras haber observado en el curso de sus vidas una parte miserable, efímeros como el humo se echan a volar, arrebatados, convencidos tan sólo de aquello que cada uno se encontró en su vagar de un lado a otro, aun cuando cada uno se jacta de haberlo descubierto todo.

iA tal extremo no son cosas observables ni audibles por los hombres ni abarcables por su inteligencia! Así que tú, ya que hasta aquí te has acercado, sabrás, pero no más que lo que el mortal entender puede alcanzar (Emped. De rer. nat. 1 = 2 D. $-K$. .).

O fragmento que corresponde ao início do poema é antropológico porque põe em jogo diferentes tensões. Em primeiro lugar, a distinção entre os sentidos e a razão. Ele sublinha a ideia de ignorância humana, que neste caso está associada com a incapacidade de mortais para conhecer a realidade através dos sentidos como fonte de conhecimento. Neste contexto: 
Empédocles como filósofo inspirado, posee conocimientos superiores que le han sido revelados, ya que la Musa habla por su boca (frs. 2-3), por lo que muestra un religioso respeto para no mancillar el ámbito de lo divino, en contraposición a quienes persiguen un éxito fácil aun a costa de hablar con temeridad de lo que no es debido (fr. 5) (Bernabé Pajares, 2008: 184).

O encerramento do fragmento recupera a idéia de movimento-viagem que estamos acompanhando, porque o discípulo veio ao mestre inspirado para saber o que sua condição antropológica lhe permitirá conhecer.

Um segundo tópico de interesse é a sua teoria dos elementos. Recordemos que não é a nossa intenção a análise do pensamento de Empédocles, mas ver como sua teoria toma corpo no âmbito de uma transmissão de conhecimento que supõe um mestre, o filósofo-poeta, um professor e um discípulo, Pausânias. De fato, o autor aborda didaticamente um tal Pausânias, chamado no fragmento 4 (D. 1-k), a quem exorta a escutar, na cena canônica de quem transmite uma mensagem e quem é convidado a ouvir: "Oyeme tú, Pausanias, hijo del sabio Anquito" (Emped. De rer. nat. $4=1$ D.-K).

A primeira formulação dos quatro elementos possui notórias conotações míticas e respondem a um fundo mágico religioso que o aproxima da tradição: "Las cuatro raíces de las cosas todas escucha lo primero cuáles son: Zeus resplandeciente, Hera dispensadora de la vida, así como Aidoneo y Nestis, que con sus lágrimas empapa el mortal hontanar" (Emped. De rer. nat. 7 = 6 D.-K.).

Além dos quatro elementos:

Lo que es nuevo en Empédocles es que, mientras para todos sus antecesores estos contrarios eran resultado de la evolución de un solo elemento originario, para él los cuatro, aire, tierra, agua y fuego, son igualmente originarios, ingénitos $e$ imperecederos, es decir, con las propiedades del ser parmenídeo, excluida la unidad. En la primera designación (fr. 7) las raíces reciben nombres divinos, lo que se aviene perfectamente con su ser eterno (Bernabé Pajares, 2008: 185).

Seguindo as linhas de continuidade e ruptura, se permitirmo-nos relacionar o tópico com a cosmogonia hesíodica, os quatro elementos têm pontos em comum com o poeta beócio, onde tà prótista, os quatro primeiríssimos, Caos, Gaia, Tártaro e Eros são identicamente originários, sem que nenhum nasça do anterior, devolvendo sua condição de nãogerados. Tal como temos sustentado, indagando o traço de um Hesíodo filósofo: 
El primer elemento a considerar es que Hesíodo presenta cuatro elementos primeros, primerísimos, sin aparente relación entre sí, y menos aún, sin relación amorosa alguna; no hay cópula, ni abrazo amoroso, ni contacto que sugiera el orden del discurso posterior, donde sí el elemento erótico parece jugar los destinos de las descendencias divinas. Allí están los cuatro primerísimos, tà prótista, sin que ninguno derive de otro (Colombani, 2016: 112).

Não obstante, o que queremos remarcar é novamente a exortação para escutar a revelação, reforçada no fragmento seguinte, ao referir ao relato, objeto de escuta:

Doble es la historia que voy a contarte. Pues una vez creció para ser uno, de múltiple que era; otra, por el contrario, de uno que era, se disoció para ser múltiple.

Doble es el nacimiento de los seres mortales, doble su destrucción;

pues el primero lo genera y lo destruye la concurrencia de las cosas todas

y el otro, al disociarse éstas de nuevo, echa a volar, una vez criado.

$Y$ estas transformaciones incesantes jamás llegan a su fin,

unas veces por Amistad concurriendo en uno todos ellos,

otras, por el contrario, separados cada uno por un lado por la inquina de Odio.

De esta forma, en la medida en que lo uno está habituado a nacer de lo múltiple

y en la medida en que a su vez, al disociarse lo uno, lo múltiple resulta,

en ese sentido nacen y no es perdurable su existencia.

Mas en la medida en que estos cambios incesantes jamás llegan a su fin,

en ese sentido son por siempre inmutables en su ciclo.

Así que escucha mi relato, pues el aprendizaje acrecienta el entender (Emped. De rer. nat. 8, 1-14 = 17, 1-14 D.-K.).

Independentemente do conteúdo, núcleo da teoria de Empédocles, queremos enfatizar o início e o fim onde ele faz alusão ao conto de prestígio dirigido a um tu que atua como interlocutor, como o é Perses, do relato de Hesíodo em Trabalhos e Dias, ou o jovem da mensagem da Deusa, em Parménides. Em todos os casos, o discurso circula em forma de relato sapiencial, carregado de um poder que, no caso de Hesíodo tem o poder potencial de transformar a conduta de seu irmão, e no de Parmênides e Empédocles, a possibilidade de conhecer o problema da verdade do ser.

Os giros discursivos que denotam a relação didática não cessam e podemos relevar algumas expressões que reforçam a imagem: "Como ya dije antes, al declarar los lindes del relato", "Y otra cosa te diré", "Vamos pues, observa como prueba de las charlas del principio lo siguiente", "Tenlo con toda claridad presente, pues de origen divino es el relato que has oído", "Mas yo voy a tomar de regreso por la senda de los cantos que recité al principio"; são algumas das expressões que dão continuidade à trama discursiva e alinhavam uma relação inscrita na dimensão do magistério como modelo de transmissão da verdade. 
Para concluir esta seção, queremos amarrar o valor do conhecimento com a vida prática, juntamente com um cenário descrito de intensa impressão poética, como forma de tramar conexão entre filosofia e poesia:

Cuantos remedios hay contra los males y un refugio contra la vejez vas a aprenderlos, pues sólo para ti daré término a todo esto. Harás cesar la furia de los vientos incansables que por cima de la tierra se abaten y arruinan con sus soplos los sembrados. Y a tu vez, si lo deseas, resucitarás compensadoras brisas y dispondrás tras la lúgubre lluvia un tiempo seco bienvenido para los hombres, y dispondrás también, después de la sequía veraniega, fluidos que moran en el éter, alimento de árboles, y sacarás de Hades el vigor de un varón fallecido (Emped. De rer. nat. $101=$ 111 D.-K.).

O fragmento 101 é eloquente na pretensão do mestre em relação com seu discípulo. Tal como sustenta Bernabé Pajares, com quem estamos de acordo:

Pretende que seu discípulo Pausânias será capaz, se seguir seus ensinos, de uma série de realizações maravilhosas. Tal pretensão contribuiu sem dúvida não pouco a sua fama de bruxo. Mesmo nos tempos modernos desenvolveu-se a interpretação de assimilar o tipo de xamã, que através do êxtase é colocado em contato com os céus e infernos e, assim, adquire seus segredos e poderes contra a morte inclusive (2008: 199).

É este um tópico inclusive importantíssimo na inscrição de Empédocles à tradição que trava poesia e filosofia. Como jogo de semelhanças, podemos pensar na figura lendária de um purificador como Epimênides: "Esta es la instalación de un personaje como Epiménides de Creta. En efecto, la alétheia que Epiménides de Creta tiene el privilegio de ver con sus propios ojos es la llanura de alétheia que el alma del iniciado aspira a contemplar" (Detienne, 1986: 18). Inclusive, no marco desta configuração religiosa, alétheia não só é complementar de Mnemosýne, mas também de Dike, já que não há distância entre o verdadeiro e o justo, e o próprio Epimênides, um xamã grego, "va a pleno día a la gruta de Zeus Diktaios, y permanece allí soñando durante numerosos años, conversa con los dioses y habla con Alétheia y Díke" (Detienne, 1986: 43). A imagem evoca a familiaridade do mestre religioso com os deuses. Ali está Epimênides "conversando com a divindade, dando depoimento da familiaridade com esse mundo estranho ao humano" (Colombani, 2016: 104 ss). Esta é a tradição na que bebe a inscrição de um Empédocles xamã, poeta e purificador, dotado do mesmo dom de vidência que um mestre de verdade em termos de M. Detienne.

Seguindo esta linha, concordamos com J. P. Vernant ao se referir a ligação entre os dois: 
En pleno siglo V, Empédocles testimonia la vitalidad de este modelo de mago, capaz de dirigir los vientos, de rescatar a un difunto del Hades y que ya no se presenta a sí mismo como un mortal, sino como un dios (2001: 78).

A singularidade destas figuras, como Epimênides ou Empédocles, é que a sua disciplina, seu modo de vida, seus exercícios espirituais, técnicas de ascetismo, falam de uma submissão a Apolo como o arquétipo da luz; um Apolo Hiperbóreo, modelo deus xamã. Há nestas figuras um elemento sobrenatural, estranho à vida comum dos mortais, um sujeito excepcional como o são o poeta, o adivinho ou o rei de justiça no contexto da província do mágico religioso.

\section{Conclusões}

O projeto do presente trabalho consistiu em relevar uma peculiar dimensão didática que parece constituir um ponto chave e indispensável nos vínculos que podem se resgatar entre poesia e filosofia. Em primeiro lugar, transitamos por alguns trechos da obra de Hesíodo, sobretudo em Trabalhos e Dias, para advertir como desempenha o poeta a função didática na relação com seu irmão Perses, que exige um traço de correção moral.

Em segundo lugar, instalamos-nos no magistério que a Deusa sustenta no Proêmio do Poema de Parménides, acolhendo ao iniciado, depois da viagem de iniciação de marcado distorção feminina, conduzido pelas luminosas filhas do Sol. A presença da Deusa foi fundamental à hora de relevar a função didática que transmite o caminho da verdade como télos possível e desejado.

Finalmente, nos localizamos no Poema de Empédocles para rastrear a mesma dimensão didática, no marco de um gesto de iniciação semelhante que se dá entre Empédocles e Pausânias. Até este ponto referimo-nos à intenção didática que sustenta a parceria formada por um mestre e um discípulo.

A outra tentativa que perseguimos foi o reconhecimento das Musas, as Helíades e a Musa, nos três autores respectivamente, para ver como se alinhava a equação saber-poder-verdade nesta esfera de pensamento, em que mesmo o mapeamento que separa e delineia os limites da poesia didática e filosofia não é cristalizado em tópoi compartimentadas. Nestes "caminhos confusos", familiarizados com a genealogia nietzschiana como uma maneira de lidar com a complexidade da realidade, a relação entre filosofia e poesia são um tema de preocupação e problematização ${ }^{15}$.

15 Ver Foucault, 1979. 
Vários talvez tenham sido os verbos que sustentaram este trabalho: transmitir, por exemplo, falar e ouvir. Dois têm sido os dominantes, já que, salientando os jogos de poder, uns falam porque conhecem a mensagem que deve ser referida e outros ouvem para, na linha dessa mensagem, conhecer aquilo que foi no princípio.

\section{Bibliografia}

BERNABÉ PAJARES, Alberto. Fragmentos presocráticos. De Tales a Demócrito. Madrid: Alianza, 2008.

COLLI, Giorgio. El nacimiento de la filosofía, Barcelona: Tusquets, 1994.

COLOMBANI, María Cecilia. Hesíodo. Una introducción crítica. Buenos Aires: Santiago Arcos, 2005.

COLOMBANI, María Cecilia, Hesíodo. Arqueología y Discurso. Una aproximación arqueológica. Mar del Plata: Editorial de la Universidad de Mar del Plata, 2016.

CORDERO, Néstor Luis. Siendo se es. La tesis de Parménides. Buenos Aires: Biblos, 2005.

CORDERO, Néstor Luis. La invención de la filosofía. Una introducción a la filosofía antigua. Buenos Aires: Biblos, 2008.

DETIENNE, Marcel. Los maestros de verdad en la Grecia Arcaica. Madrid: Taurus, 1986.

ELIADE, Mircea. Mito y realidad. Colombia: Labor, 1991.

FOUCAULT, Michel. El orden del discurso. Barcelona: Tusquets, 1983.

FOUCAULT, Michel. Nietzsche, la historia, le genealogía en Microfísica del poder0 Madrid: Ediciones La Piqueta, 1979.

GERNET, Louis. Antropología de la Grecia Antigua, Madrid: Taurus, 1981.

GIGON, Olof. Problemas fundamentales de la filosofía griega. Buenos Aires, Compañía General Fabril Argentina, 1962.

GIGON, Olof. Los orígenes de la filosofía griega. Buenos Aires: Gredos, 1985. HESÍODO, Obras y fragmentos. Traducción y notas de Aurelio Pérez Jiménez y Alberto Martínez Díez. Madrid: Gredos, 2000.

MONDOLFO, R. El pensamiento antiguo, Buenos Aires, Losada, 1980.

VERNANT, J.-P. Mito y religión en la Grecia Antigua, Barcelona, Ariel, 2001. 